\title{
Program minimalistyczny w badaniach diachronicznych: ograniczenia i korzyści
}

\section{Janusz Malak}

Uniwersytet Opolski

\section{Wstęp}

Tytuł niniejszego tekstu sugeruje, że będzie on opisem roli, jaką może odgrywać program minimalistyczny w badaniach diachronicznych nad językiem, a także korzyści, jakie mogą płynąć z zastosowania tego paradymatu, a co pozostaje poza opisem przy jego wykorzystaniu. Skojarzenie tych dwóch obszarów językoznawczych jest dość ryzykowne, gdyż, jak to będzie wykazane w dalszych częściach tego szkicu, porównując cele, jakie stawiają badania diachroniczne i program minimalistyczny, mają się one do siebie nijak. Właściwie problem będzie ujęty w inny sposób. Mianowicie poprzez krótką prezentację istoty i celów tych dwóch domen językoznawczych mamy nadzieję wykazać, że zastosowanie programu minimalistycznego w badaniach diachronicznych może przyczynić się do zrozumienia istoty przyczyn niektórych zmian językowych z jednej strony, jak również dane płynące z badań diachronicznych przy zastosowaniu instrumentarium programu minimalistycznego mogą być przydatne do zmodyfikowania pewnych aspektów samego paradygmatu, a w szczególności jednego z jego elementów, tj. derywacji, z drugiej. Innymi słowy, minimalistyczny paradygmat jako forma opisu języka i badania diachroniczne jako obszar badań mogą być wzajemnymi beneficjentami.

\section{Badania diachroniczne: zakres, cele i możliwości eksplikacyjne}

Aby móc ocenić przydatność programu minimalistycznego do badań diachronicznych, należy wpierw przyjrzeć się temu, co wchodzi w zakres tychże badań. Według Kazimierza Polańskiego (1993: 110): „,[b]adając jęz. w tym [tj. diachro- 
nicznym - J. M.] ujęciu skupia się uwagę na kolejnych zmianach i przekształceniach w jego strukturze (w słownictwie, składni, morfologii, fonologii)". Jacek Perlin (2004) podkreśla, że przedmiotem zainteresowania językoznawstwa diachronicznego są zmiany $w$ języku na wszystkich jego poziomach $i$ we wszystkich jego podsystemach. Wymienia takie zmiany, jak: fonetyczne, fonologiczne, prozodyczne, morfologiczne, składniowe, stylistyczne, socjolingwistyczne, pragmatyczne. Do badań diachronicznych wchodzą również badania nad etykietą językową. A zatem w zakres badań diachronicznych wchodzą wszystkie aspekty języka w całej jego złożoności, jeżeli chodzi o jego strukturę, jak i użycie. Natomiast celem badań diachronicznych będzie opis i katalogowanie zmian, jakie miały miejsce $\mathrm{w}$ poszczególnych systemach języka w różnych przedziałach czasowych. Jak sygnalizuje Perlin (2004: 16), w badaniach diachronicznych ,[i]stotne jest podejście do materiału językowego od strony dynamicznej, widzenie nie stanu, ale ruchu, transformacji, przekształcenia".

Takie podejście do badań diachronicznych w dużej mierze determinowane jest sposobem definiowania języka i źródłem danych do badań tego typu. Język definiowany jako „system znaków (prymarnie dźwiękowych, wtórnie pisanych) służących do porozumiewania się w obrębie danej społeczności" (Polański 1993: 240) jawi się jako produkt. Dla językoznawcy diachronicznego ten produkt będzie się manifestował w różnego rodzaju tekstach historycznych i inskrypcjach, a więc w jego wtórnej manifestacji. Analiza tekstów historycznych dostarcza danych do analiz poziomu fonetycznego poprzez analizę ortografii, co, $\mathrm{z}$ kolei, daje punkt wyjścia do analiz poziomu fonologicznego. Badania nad strukturą słowa będą punktem wyjścia do badań nad fleksją z jednej strony i znaczeniem słów $z$ drugiej.

Wynikiem takich badań były gramatyki historyczne, pisane dla poszczególnych języków, jak również gramatyki porównawcze całych rodzin języków, których pierwotnym celem było zrekonstruowanie danego prajęzyka, który nie został zarejestrowany w żadnym zaświadczonym tekście. Gramatyki historyczne zawierają pewne próby wyjaśnienia zmian językowych. Jednakże te wyjaśnienia bardziej dotyczą poziomu fonologicznego i morfologicznego. Opis poziomu składniowego dalej pozostaje tylko skatalogowanym rejestrem kolejnych zmian wyznaczonych i zdefiniowanych składników. Tak pisane były gramatyki historyczne dla języka polskiego, przywołując dla przykładu Gramatyke historyczna języka polskiego Stanisława Rosponda (1971), Historię języka polskiego Zenona Klemensiewicza (1974), Gramatyka historyczna języka polskiego Krystyny Długosz-Kurczabowej i Stanisława Dubisza (2006). Podobny schemat można znaleźć w opisach rozwoju języka angielskiego, zawartych w ogromnej liczbie publikacji, dlatego też ograniczymy się w tym miejscu do wymienienia jednego monumentalnego opracowania, tj. siedmiotomowej The 
Cambridge History of the English Language pod redakcją Richarda M. Hogga (1992-1999), gdzie każdy aspekt badań diachronicznych ma swoje odbicie w osobnym rozdziale. Nasze rozważania, dotyczące możliwości eksplikacyjnych tego typu badań, ograniczymy do języka angielskiego.

Czytając liczne opracowania, poświęcone historii tego języka, można zauważyć, że w większości przypadków są one katalogami zmian i zawierają opis:

1. Zmian w systemie fonologicznym, charakteryzujących się m.in. zanikiem długości, jako cechy dystynktywnej w podsystemie spółgłoskowym, pojawieniem się w okresie średnioangielskim nowych fonemów spółgłoskowych (spółgłoski trące dźwięczne uzyskują status fonemów), zanikiem jednego fonemu spółgłoskowego (spółgłoska trąca welarna znika z podsystemu spółgłoskowego), zmianami w podsystemie samogłoskowym, które powiązane są $\mathrm{z}$ reanalizą sylaby $\mathrm{w}$ niektórych średnioangielskich dialektach. Wszystkie te zmiany dają się wyjaśnić poprzez uwarunkowania wewnątrzsystemowe, tzn. wahnięcia w jednym podsystemie mogą służyć jako wyjaśnienie modyfikacji w innym, jak i zewnętrzne, tj. poprzez zapożyczenia z innych języków.

2. Zmian morfologicznych, które manifestują się w prawie całkowitym zaniku fleksji. Wyjaśnianie tego zjawiska uwarunkowaniami wewnątrzsystemowymi jest jednak mało przekonywające. W większości opracowań, dotyczących historii morfologii angielskiej, zanik fleksji angielskiej tłumaczony jest jako wynik redukcji nieakcentowanej samogłoski oraz neutralizacja jakościowa dwóch fonemów nosowych $/ \mathrm{m} / \mathrm{i} / \mathrm{n} / \mathrm{do} / \mathrm{n} / \mathrm{w}$ pozycji końcowej w wyrazie i późniejszym jego zanikiem.

3. Zmian składniowych, manifestujących się zanikiem pewnych konstrukcji, np. zdań bezpodmiotowych, strony biernej pośredniej, zanikiem innych opcji zdaniowych, takich jak utrata cechy V-2 (tj. pojawiania się czasownika w formie osobowej $\mathrm{w}$ drugiej pozycji, jeżeli pozycję początkową $\mathrm{w}$ zdaniu zajmuje składnik, który nie jest podmiotem; właściwość ta cechuje większość języków zachodniogermańskich, takich jak np. niemiecki czy niderlandzki) prowadząca do skostnienia szyku wyrazów, utrata szyku wyrazów, w którym dopełnienie bliższe poprzedza czasownik (OV).

4. Zmian leksykalnych, manifestujących się obecnością w średnio- i nowoangielskim wielu obcych jednostek leksykalnych, co odzwierciedla liczne kontakty anglofonów z użytkownikami innych języków.

Podczas gdy wyjaśnienia dotyczące zmian fonologicznych, oparte na faktach wewnątrz- i zewnątrzsystemowych, wydają się przekonywające (kwestie zależności prozodycznych oraz wpływ jednego systemu fonologicznego na drugi), jak również wyjaśnienia zmian leksykalnych nie nastręczają większych trudności, to zmiany manifestujące się $\mathrm{w}$ zaniku fleksji i $\mathrm{z}$ tym powiązane zmiany w składni angielskiej pozostają bez wytłumaczenia. Kwestia pożyczek 
składniowych jest raczej mało prawdopodobna. April M. S. McMahon (1994) twierdzi za Sarahą G. Thomason i Terrence'em Kaufmanem (1988), że pożyczki strukturalne są możliwe, jeżeli odpowiadają tendencjom rozwojowym języka pożyczającego. W tym szkicu będzie prezentowany bardziej radykalny pogląd, a mianowicie pożyczki składniowe nie są możliwe ze względu na jeden aspekt, który nie jest brany pod uwagę $\mathrm{w}$ badaniach diachronicznych, utrzymanych w duchu strukturalistycznym. Tym aspektem jest interpretowalność struktur składniowych. Interpretacja jest ważnym elementem programu minimalistycznego. Dlatego też istniejące opisy zmian systemów fleksyjnego i składniowego języka angielskiego, jak i pozostałych języków, pisane w duchu niegeneratywnym, zdają się być jedynie katalogiem zdań, umiejscowionym sekwencyjnie w czasie, w których próby wyjaśnienia zmian składniowych charakteryzują się dużym stopniem spekulatywności.

\section{Program minimalistyczny: zarys i główne cele}

Program minimalistyczny jest najświeższym wcieleniem gramatyki generatywnej, która zaczęła swój żywot w latach pięćdziesiątych ubiegłego stulecia i stawia sobie za cel scharakteryzowanie języka, lub też czegoś w rodzaju metajęzyka, który traktowany jest jako jeden z organów umysłu ludzkiego i jest człowiekowi dany jako wynik ewolucji, z którym człowiek przychodzi na świat. Organ ten składa się z potencjalnie istniejących reguł uniwersalnych, umożliwiających człowiekowi szybkie nabywanie języka ojczystego. Tutaj jawi się różnica w podejściu do języka, co będzie determinowało podejście językowców diachronicznych do badanej materii pracujących z użyciem programu minimalistycznego. Jak wcześniej wspomniano, język w niegeneratywnych badaniach diachronicznych jest traktowany jako system znaków. W podejściu generatywnym język jest sparametryzowaną umiejętnością tworzenia arbitralnych znaków językowych, u podstawy której leży genetycznie uwarunkowany stan początkowy $\mathrm{S}_{0}$, zwany gramatyką uniwersalną (Universal Grammar).

A zatem wysiłki generatywistów skupiają się na opisie i scharakteryzowaniu gramatyki uniwersalnej. Jednym z problemów, z którymi borykają się generatywiści, jest sposób, w jaki dźwięk łączy się ze znaczeniem/interpretacją. Zakłada się, że tym spoiwem jest składnia. Oznacza to, że gramatyka generatywna we wszystkich swoich wcieleniach jest składnio-centryczna. Należy nie zapominać, że program minimalistyczny, jako kolejna wersja gramatyki generatywnej, nie jest teoria, jak to było w przypadku teorii standardowej (Standard Theory), rozszerzonej teorii standardowej (Extended Standard Theory), czy też 
teorii rząu i wiązania (Government and Binding Theory), tylko projektem, który ciągle ewoluuje. Wystarczy porównać kolejne wersje instrumentarium programu minimalistycznego postulowane w pracach Noama Chomsky'ego (1995; 1999; 2000). Nie będziemy w tym miejscu skupiać się na opisie wszystkich aspektów tego projektu i jego kolejnych modyfikacjach, gdyż bardzo wyczerpującą syntezę tego podejścia do języka można znaleźć u Przemysława Tajsnera $(2006)^{1}$. Skoncentrujemy się tylko na tych aspektach tego projektu, które są przydatne w badaniach diachronicznych.

Jedną z wielu różnic, które charakteryzuje program minimalistyczny w porównaniu do poprzednich wersji gramatyki generatywnej, jest brak takich poziomów reprezentacji, jak struktura głęboka i struktura powierzchniowa. Jedynymi poziomami reprezentacji są dwa łączniki z dwoma składnikami interpretacyjnymi, tj. forma fonologiczna (PF) - łącznik z modułem percepcyjno-artykulacyjnym i forma logiczna (LF) - łącznik z modułem interpretacyjnym, który sprzężony jest z systemem logiczno-intensjonalnym. Modele poprzedzające program minimalistyczny można opisać jako paradygmaty statyczne, tj. takie, które opierały się na przedstawianiu struktur, mających odzwierciedlać zależności leksykalne, a po części też konfiguracyjne, w przypadku struktury głębokiej, oraz struktur, będących wynikiem przekształceń tworów głębokich, tj. struktury powierzchniowej. Program minimalistyczny, wolny od poziomów reprezentacji z poprzednich modeli, jest paradygmatem dynamicznym, gdzie wytworzenie znaku językowego opiera się na derywacji bazującej na konkatenacji elementów leksykalnych pobranych z leksykonu. Podczas gdy wcześniejsze wersje gramatyki generatywnej kładły nacisk na konfiguracyjność składników, to program minimalistyczny opiera się na związkach relacyjnych, zachodzących między składnikami. Jak będzie wykazane później, ma to swoją zaletę, jeżeli chodzi o badania diachroniczne.

Tworzenie wyrażenia językowego, oparte na derywacji, charakteryzuje się optymalnością, skutecznością i ekonomią. Podstawą derywacji jest konkatenacja elementów leksykalnych, które są agregatami trzech rodzajów cech, tj. fonologicznych $(\pi)$, logicznych $(\lambda)$ i formalnych $(\varphi)$. Wstępną fazą derywacji jest 'numeracja początkowa', będąca zestawem jednostek leksykalnych, pobranych z leksykonu. Jest ona punktem wyjścia do konkatencji tych jednostek za pomocą operacji - wybierz (Select) i łącz (Merge). Oprócz jednostek leksykalnych, w derywacji pojawiają się jednostki funkcjonalne, takie jak: lekki czasownik (light verb v), czas (T) i spójnik wprowadzający zdania podrzędne (C). Lekki czasownik jest jednostką funkcjonalną, współwystępującą $\mathrm{z}$ czasownikiem

\footnotetext{
${ }^{1}$ Polskie odpowiedniki angielskich terminów minimalistycznych zostały zapożyczone od Tajsnera (2006).
} 
leksykalnym (V). Jest ona odpowiedzialna za semantyczny wybór zewnętrznego argumentu z jednej strony i ustalenia strukturalnego przypadka accusativus $\mathrm{z}$ drugiej. Jednostka $\mathrm{T}$ odpowiedzialna jest za przypisanie przypadka nominativus semantycznemu składnikowi rzeczownikowemu, który został włączony do derywacji $\mathrm{W}$ pozycji pierwszego określnika (spec) czasownika lekkiego. Jednostka C, która obecna jest w każdym typie zdań, tj. w zdaniach podrzędnych, jak i głównych, jest miejscem, gdzie znajdują się informacje dotyczące siły illokucyjnej danego zdania. Jeżeli zdanie jest składnikiem podrzędnym, to C może być zleksykalizowane jako that lub if, jeżeli siła illokucyjna takiego zdania to, odpowiednio, twierdzenie i pytanie. Jeżeli zdanie jest składnikiem głównym, to $\mathrm{C}$ albo nie ma realizacji fonologicznej $\mathrm{w}$ przypadku zdania twierdzącego lub będzie miało zaimek pytajny (wh-word) w pozycji początkowej. Zakłada się, że w przypadku języka angielskiego i polskiego zaimki pytajne fonologicznie realizowane są w wyniku przemieszczenia z miejsca, w których są one logicznie powiązane $\mathrm{z}$ elementami leksykalnymi i $\mathrm{w}$ których, według założeń programu minimalistycznego, zostały włączone do derywacji do określnika C.

$\mathrm{W}$ tym miejscu pojawia się bardzo istotny element programu minimalistycznego, mianowicie kojarzenie materiału leksykalnego z elementami funkcjonalnymi. Wszystkie jednostki, tj. leksykalne i funkcjonalne, zdolne są do tworzenia fraz, w których będą funkcjonowały jako ośrodki (heads). Według minimalnej struktury frazowej (Bare Phrase Structure), wszystkie maksymalne projekcje danego ośrodka będą tworzone według struktury (1):

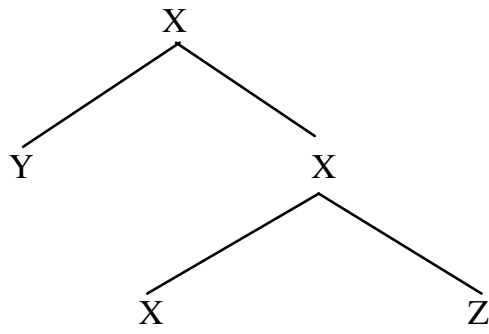

w której status danego składnika jest determinowany jego rolą w derywacji, tj. czy funkcjonuje jako składnik wybierający, czy jako składnik wybierany. Zakłada się, że, aby być składnikiem, który może wchodzić w interakcje z innymi frazami, musi on być projekcją maksymalną, a więc oznaczenia kreskowe, typowe dla wcześniejszych modeli generatywnych, są zbędne w tym przypadku. Element $X$, który jest elementem minimalnym, wybiera element $\mathrm{Z}$ i przez to, że razem tworzą element $\mathrm{X}, \mathrm{Z}$ traci swój minimalny charakter i jest interpretowany jako projekcja maksymalna. $\mathrm{W}$ momencie, gdy $\mathrm{X}$ wybiera $\mathrm{Y}$, 
tworząc razem $X$, ten ostatni również traci swój minimalny charakter, a X poprzez wybranie tych dwóch elementów zaspokaja niejako swoje semantyczne lub formalne potrzeby i staje się składnikiem, który sam może być wybierany. Dla nas istotna jest pozycja zajmowana przez Y. Jest to pozycja określnika, która może pełnić funkcję semantyczną, jak to jest w przypadku niektórych klas czasowników, semantyczną i formalną, jak to jest w przypadku czasownika lekkiego (v), lub czysto formalną, jak to jest w przypadku T i C. Funkcjonalność określnika polega na tym, że służy on jako miejsce, w którym można ewaluować i dopasowywać cechy formalne $\varphi$, które wchodzą w skład elementów leksykalnych, z odpowiednimi cechami formalnymi ośrodków funkcjonalnych $v$, T i C. To dopasowywanie i ewaluacja cech następuje poprzez zgodność ośrodka i określnika. Ten zabieg derywacyjny związany jest z operacją - przemieść, która przemieszcza czasownik V do kolejnych ośrodków funkcjonalnych w celu ustanowienia domeny dopasowywania/sprawdzania (checking domain). Czasownik jest doczepiany do tych ośrodków. Natomiast cechy są dopasowywane i ewaluowane przez składniki rzeczownikowe. I tak wyrażenie rzeczownikowe, które jest umieszczane $\mathrm{w}$ derywacji jako dopełnienie $\mathrm{V}$, przemieszcza się do określnika czasownika lekkiego $v$. Tam są dopasowywane i ewaluowane cechy nominalne. W tym momencie nieinterpretowalna cecha 'przypadek', jest dopasowywana, ewaluowana i wymazywana. W ten sposób derywacja pozbywa się cechy, która zakłóca interpretację, tzn. funkcjonuje jako wirus. Wyrażenie rzeczownikowe, umieszczane w drugim określniku czasownika lekkiego $v$, przemieszcza się do określnika T, gdzie jego cecha 'przypadek' jest dopasowywana do analogicznej cechy $\mathrm{T}$, ewaluowana i wymazywana, przez co to wyrażenie nosi znamiona przypadka nominativus. Przyimki pytajne przemieszczają się tak jak składniki rzeczownikowe z tym, że docelowym ich miejscem jest określnik C.

Innowacją tego modelu w stosunku do modeli wcześniejszych jest założenie, że to przemieszczenie jest widoczne w komponencie fonologicznym lub też jest niewidoczne, ale obecne $\mathrm{w}$ komponencie interpretacyjnym, tj. $\mathrm{w}$ formie logicznej. Widzialność czy też niewidzialność przemieszczenia danego składnika wiąże się $\mathrm{z}$ następnym elementem programu minimalistycznego. Tym elementem jest punkt przekazania (Spell-Out), gdzie derywacja w danym momencie jest pozbawiana wszystkich cech fonologicznych derywatu, a to, co zostaje, podlega dalszemu procesowi derywacyjnemu, który już jest bardziej 'rozumiany' niż 'widziany' na poziomie zewnętrznym, tj. fonologicznym. Istotne jest to, aby otrzymany derywat był w pełni interpretowalny, tzn. zgodny z substancjami na dwóch łącznikach, tj. PF i LF, diametralnie od siebie różnych. Cechą, która te zależności reguluje, jest pełna interpretacja (Full Interpretation). Jak wspomniano wcześniej, program minimalistyczny jest ciągle ewoluującym 
projektem i jednym z elementów tego projektów, który stale ulega zmianie, jest liczba punktów przekazania (Spell-Out). We wczesnym minimalizmie derywacja charakteryzowała się jednym punktem przekazania. W późniejszych modyfikacjach tego modelu, np. Chomsky (1999), derywacja charakteryzuje się fazowością, dzięki wielokrotnemu punktowi przekazania (multiple Spell-Out). Nie będziemy się tą kwestią zajmować, gdyż nie jest ona istotna, jeżeli chodzi o relację pomiędzy programem minimalistycznym a badaniami diachronicznymi. Wystarczy wspomnieć, że moment, w jakim pojawia się punkt przekazania, będzie odpowiedzialny za różnice parametryczne między językami. Wolfram Hinzen (2009) ilustruje to na przykładzie derywowania zdań pytajnych $\mathrm{z}$ kilkoma zaimkami pytajnymi. Nieprzemieszczone zaimki pytajne $\mathrm{w}$ języku chińskim, przemieszczony tylko jeden zaimek pytajny w takich językach, jak: angielski czy francuski, czy też przemieszczone dwa zaimki pytajne, jak to ma miejsce w serbskim, chorwackim czy bułgarskim, tłumaczone są momentem, w jakim pojawi się punkt przekazania, tzn. czy stanie się to we wczesnych etapach derywacji, czy w późniejszych. Jak będzie wykazane później, ten element programu minimalistycznego może okazać się przydatny do wyjaśniania pewnych zmian składniowych.

\section{Badania diachroniczne i program minimalistyczny: symbioza czy autonomiczna odrębność?}

Patrząc na cele, jakie stawiają sobie językoznawcy zajmujący się programem minimalistycznym i historią jakiegoś języka, można odnieść wrażenie, że te dwa obszary językoznawcze, jak zasygnalizowano na początku tego szkicu, mają się do siebie nijak i ich obopólna relacja powinna charakteryzować się wzajemną autonomiczną odrębnością. Do takiego wniosku można dojść, analizując cele, jak i metody badawcze, charakteryzujące te dwa obszary. Jak już wykazano, celem, jaki sobie stawiają minimaliści, jest możliwie najpełniejszy opis wewnętrznej właściwości każdego użytkownika języka, stanowiącej zarazem jeden z komponentów ludzkiego umysłu, odpowiedzialny za znajomość języka. Ta właściwość określana jest jako zdolność językowa (language faculty). W zakres zainteresowań i badań minimalistów wchodzą wszystkie ludzkie języki. Językoznawstwo generatywne, $\mathrm{w}$ tym także program minimalistyczny, aspiruje do dyscyplin empirycznych $\mathrm{w}$ tym sensie, że poprzez określenie stopnia akceptowalności struktur, które są tworzone na podstawie introspekcji językowej samych badaczy, jak i intuicji użytkowników języka w ogóle, jako materiał weryfikujący ustala się uniwersalne ograniczenia w tworzeniu syntagm. To 
odpowiada eksperymentowi w takich empirycznych dziedzinach, jak fizyka czy chemia. Struktury nieakceptowalne wyznaczają granicę, poza którą kompetencja językowa nie wychodzi i w ten sposób opisuje się istotę języka, a raczej istotę mediatora między dźwiękiem a znaczeniem. A zatem w przypadku badań minimalistycznych, źródłem danych są użytkownicy języka.

Badania diachroniczne trudno nazwać jest badaniami empirycznymi w sensie przedstawionym powyżej. Jak już wspomniano, dane do badań diachronicznych pochodzą głównie z zaświadczonych tekstów historycznych. Teksty te można uważać za ugraficznione wytwory, będące odbiciem kompetencji językowej autorów. $Z$ dużym prawdopodobieństwem można przyjąć, że wszystkie dostępne teksty będą tworami w pełni interpretowalnymi i przez to akceptowalnymi. Stąd też niemożność otrzymania danych negatywnych, które stanowią część badań w obszarze minimalistycznym. Natomiast biorąc pod uwage hipotezę jednolitościową (uniformitarian hypothesis), zaproponowaną przez Williama Crofta (2003: 233), której treść zawiera się w stwierdzeniu, że przeszłe języki nie różnią się w naturze od obecnych, można bezpiecznie założyć, że właściwości, kategorie składniowe oraz zależności, zachodzące między składnikami w wyniku przemieszczeń, występujących w opisie minimalistycznym różnych języków, będą również ważne w opisie przeszłych stadiów historii badanego języka. Ian G. Roberts (2007) odnosi tę hipotezę do wszystkich języków w całym okresie istnienia naszego gatunku biologicznego. To znaczy, że, przykładowo, teksty staro- i średnioangielskie będą odbiciem gramatyki, opartej na derywacji, w której pobierano z leksykonu jednostki leksykalne, będące agregatami trzech rodzajów cech, jak również jednostki funkcjonalne, gdzie te jednostki łączono ze sobą poprzez operację - łącz (Merge), a następnie kojarzono je z jednostkami funkcjonalnymi. Derywacje te charakteryzowały się tymi samymi uwarunkowaniami i ograniczeniami, jak derywacje we wszystkich obecnie badanych językach. A zatem program minimalistyczny może być w symbiozie $\mathrm{z}$ badaniami diachronicznymi poprzez zaadaptowanie tego paradygmatu jako perspektywy badawczej.

Zaadaptowanie programu minimalistycznego w badaniach diachronicznych wraz z całym jego instrumentarium jest obciążone ograniczeniami, ale również oferuje pewne korzyści. Niedogodnością jest to, że poza analizą przeprowadzoną w paradygmacie minimalistycznym, pozostaną takie poziomy, jak: fonologiczny, morfologiczny, semantyczny i leksykalny. Architektura programu minimalistycznego umieszcza poziomy fonologiczny i morfologiczny gdzieś w okolicach formy fonologicznej (PF). Należy również pamiętać, że według prezentacji programu minimalistycznego, zaproponowanej przez Chomsky'ego (1995), fleksja należy do leksykonu w tym sensie, że jednostki leksykalne pojawiają się w 'numeracji' już w formie odmienionej. Również ten paradygmat nie dostarczy 
możliwych odpowiedzi na pytanie, co leżało u podstaw utraty fleksji w takich językach, jak angielski czy niderlandzki. Poziom semantyczny będzie za formą logiczną (LF). Pozostaje tylko możliwość badania składni, co wynika ze składniocentrycznego charakteru paradygmatu minimalistycznego. Przyjąwszy minimalistyczny paradygmat, można założyć, że analizując konfiguracje składników, które są reprezentowane w analizowanych tekstach, i przyjmując derywacyjny charakter procesów, które doprowadziły od ich wytworzenia, można odtworzyć zmiany $\mathrm{w}$ samym procesie derywacyjnym i tym samym wyszczególnić pewne tendencje rozwojowe derywacji w badanym języku. W ten sposób gramatyka generatywna w swojej ostatniej wersji dostarcza językoznawcom diachronicznym obiekt badania, tj. składnię, a mówiąc precyzyjniej, pewne aspekty derywacji składniowej, np. przesunięcie danego składnika $\mathrm{w}$ jawnej składni (overt syntax), tj. pomiędzy operacją - łącz (Merge) a punktem, względnie punktami, przekazania (Spell-Out), lub w składni niejawnej (covert syntax), tj. między punktem przekazania (Spell-Out) a LF. To pierwsze zjawisko będzie widoczne na PF i, tym samym, będzie miało swoje odbicie w tekstach, to ostatnie będzie miało walor interpretacyjny i będzie miało inne odzwierciedlenie w tekstach.

Upraszczając trochę obraz badań diachronicznych, można zauważyć, że wyjaśnienie zmian fonologicznych i leksykalnych w jakiś sposób koreluje z dwoma składnikami, zaangażowanymi $\mathrm{w}$ derywowanie i interpretowanie tworów składniowych. Zmiany fonologiczne zachodzą w substancji fonomorfologicznej, do której PF jest łącznikiem, i rządzą się własnymi prawami. Natomiast zmiany leksykalne będą związane ze strukturą leksykonu, który służy jako zbiór jednostek leksykalnych (Lexical Items) i z których tworzy się składniowe derywaty. Po części tłumaczyłoby to, dlaczego prawa rządzące zmianami w tych dwóch komponentach są jakościowo odmienne, gdyż substancje, które są im przypisane, charakteryzują się odmiennymi właściwościami.

Istotna w tym punkcie jest inna cecha podejścia minimalistycznego do badań diachronicznych. Ewolucję składniową analizowanego języka można postrzegać jako zanik pewnych struktur składniowych, które są zastępowane przez inne struktury. Biorąc pod uwagę regułę pełnej interpretacji (Full Interpretation), problem badawczy można sformułować następująco: jakie uwarunkowania miały wpływ na to, że dane struktury składniowe zanikły, czyli stały się nieinterpretowalne dla późniejszych pokoleń użytkowników badanego języka. Czy jest to kwestia samego użycia, czy też zanik danych syntagm wiąże się ze zmianami w obrębie derywacji. Ten komponent programu minimalistycznego wyklucza również możliwość wspomnianych już pożyczek składniowych. Mało prawdopodobna jest możliwość zapożyczenia syntagm, które dla użytkowników języka zapożyczającego będą nieinterpretowalne. 


\section{Program minimalistyczny w badaniach diachronicznych - stare problemy, nowe rozwiązania}

Zaprezentowane powiązania badań diachronicznych z programem minimalistycznym sugerują, że badacze historii języków mogą spojrzeć na problemy związane $\mathrm{z}$ ewolucją składni badanego języka z nowej perspektywy. Może to dać w efekcie nowe opracowania, dotyczące składni historycznej, które nie będą już tylko suchym rejestrem i katalogiem zmian składniowych, jak to ma miejsce w monumentalnej czterotomowej publikacji Fredericusa Th. Vissera (1963-1971), dotyczącej historii składni angielskiej. Posłużymy się tutaj konkretnymi przykładami, zaczerpniętymi z historii języka angielskiego.

Schyłek okresu średnioangielskiego i początek nowoangielskiego, tj. okres między początkiem XV wieku a końcem XVI wieku obfituje w innowacje składniowe, które nie pojawiają się lub pojawiają się marginalnie we wcześniejszych tekstach. Do nich można zaliczyć pojawienie się nowej kategorii składniowej czasownika posiłkowego (Auxiliary), np. do jako operatora w zdaniach pytających i przeczących, tworzenie się całego szeregu czasownikowych konstrukcji peryfrastycznych, oddających czas i aspekt (chodzi tu o angielski Perfect i Progressive) w stronie czynnej i biernej, stały wzrost pojawiania się struktur ACI, które są interpretowane jako struktury predykatywne. Tym innowacjom składniowym towarzyszył stopniowy zanik zdań pytających, tworzonych przez inwersje $\mathrm{z}$ wszystkimi czasownikami, tj. leksykalnymi i posiłkowymi, oraz stopniowy zanik zdań przeczących, których cechą było pojawianie się negatora not po czasowniku, leksykalnym i posiłkowym. W obydwu przypadkach w późniejszych stadiach rozwoju składni angielskiej rolę operatora w pytaniach i przeczeniach wzięły na siebie czasowniki posiłkowe. Tak to jest mniej więcej przedstawiane w opracowaniach, dotyczących składni historycznej języka angielskiego (Denison 1993; Allen 1995; Traugott 1992). Pytanie, które wiąże się z opisanymi obserwacjami, brzmi: czy pojawianie się powyższych innowacji składniowych w dość krótkim, bo dwustuletnim, okresie i jednoczesny stopniowy zanik starszych struktur składniowych jest zbiegiem okoliczności, czy też można te wszystkie zmiany ze sobą powiązać i wytłumaczyć poprzez znalezienie jakiegoś wspólnego mianownika.

Opierając się na publikacji Vissera, można dojść do wniosku, że historie składni, pisane w podejściu niegeneratywnym, są skazane na bycie tylko katalogiem zmian, umiejscowionym na osi czasu. Nic więcej poza tym nie da się stwierdzić. Patrząc jednak na te zjawiska językowe $\mathrm{z}$ derywacyjnego punktu widzenia, oferowanego nam przez program minimalistyczny, można ujrzeć więcej i dostrzec szukany wspólny mianownik, co będzie miało dużą wartość 
eksplikacyjną. Nie wdając się w szczegóły techniczne, charakteryzujące minimalistyczny paradygmat, można przyjąć, że głównym czynnikiem, powodującym zanik możliwości tworzenia pytań i przeczeń w sposób wspomniany powyżej, jest zanik jawnego przemieszczenia czasownika z miejsca, w którym został on wstawiony podczas numeracji, tj. po pozyskaniu go z leksykonu i wstawieniu do zestawu leksykalnego (Lexical Array, LA), do wyższych ośrodków funkcjonalnych. W programie minimalistycznym zakłada się, że składniki przemieszczają się w składni jawnej (w nowszych wersjach programu minimalistycznego jest to operacja - kopiuj i łącz (Copy and Merge)) po to, aby sprawdzić, dopasować, i, w przypadku nieinterpretowalności, wymazać mocne cechy, które są obecne w nich, jak również w ośrodkach funkcjonalnych, takich jak $v$, T, Foc (focus), Top (topic). Czasownik przemieszcza się do kolejnych ośrodków, jest z nimi kojarzony poprzez doczepienie (adjunction) w celu wytworzenia 'domeny sprawdzania' (Checking Domain). Ten właśnie element derywacji, tj. jawne przemieszczenie czasownika, tzn. przed punktem przekazania (Spell-Outem), lub niejawne, tj. po tym punkcie przekazania, wydaje się odpowiedzialne za istnienie możliwości tworzenia pytań przez inwersję czasowników leksykalnych, jak i tworzenie przeczeń przez kojarzenie czasowników leksykalnych z not. Brak możliwości przesunięcia czasownika w komponencie jawnym derywacji i pozostawienie kojarzenia czasownika z wyższymi ośrodkami funkcjonalnymi w komponencie niejawnym (covert) jest przyczyną wyodrębnienia się kategorii czasowników posiłkowych, co dało początek szybkiemu pojawieniu się całego szeregu angielskich czasownikowych formacji peryfrastycznych, pojawianiu się czasownika posiłkowego do w pytaniach i przeczeniach, który można traktować jako rekompensatę braku możliwości przemieszczenia czasownika leksykalnego w komponencie jawnym. To również może mieć związek z powstaniem czegoś, co w literaturze generatywnej nazwano zdaniem wyjątkowym (Exceptional Clause). Wyjątkowość tego ostatniego tworu polega na tym, że pomimo braku wyrażeń rzeczownikowych z oznaczeniem mianownika i braku zgody pomiędzy składnikiem funkcjonującym jako podmiot a frazą czasownikową funkcjonującą jako orzeczenie, twór ten interpretowany jest jako struktura orzeczeniowa. We wcześniejszych okresach historycznych języka angielskiego, takie struktury istniały, ale były ograniczone do garstki czasowników, oznaczających wrażenia sensoryczne, np. staroangielskie hieran 'słyszeć' czy seon 'widzieć', lub też sprawczość, np. hatan 'rozkazać', czy latan 'pozwolić'. Co więcej, oznaczenie wyrażenia bezokolicznikowego było sygnalizowane w odmienny od nowoangielskiego sposób. Jak już wspomniano, samo przemieszczenie elementów, czy to w komponencie jawnym czy niejawnym, jest wymuszane siłą lub słabością danej cechy. 
Abstrahując od samego pojęcia cechy i jej siły czy słabości, można założyć, że któryś z ośrodków funkcjonalnych utracił siłę którejś ze swoich cech, co spowodowało uwięzienie czasownika $\mathrm{w}$ obrębie $v \mathrm{P}$. To, z kolei, mogło doprowadzić do zmiany parametru $\mathrm{z}$ jawnego przesunięcia czasownika podczas derywacji do jego niejawnego odpowiednika. Innymi słowy, zmieniała się wartość derywacji poprzez wcześniejsze wprowadzenie do derywacji punktu przekazania (Spell-Out). Jak nietrudno zauważyć, jest to podobny mechanizm do tego, który stoi za różnicami między językami, jeżeli chodzi o miejsce zaimków pytajnych (Hinz 2009). Powyższy przykład wykazuje korzyść eksplikacyjna, płynącą z zastosowania instrumentarium minimalistycznego. Przemieszczenie czasownika $\mathrm{w}$ trakcie derywacji do ośrodka $\mathrm{T}$ przed punktem przekazania (Spell-Out) lub przeniesienie tej operacji do części po tym punkcie przekazania zdaje się być tym poszukiwanym wspólnym mianownikiem i pozwala spojrzeć na składnię jako wynik derywacji. Kolejną korzyścią, płynącą z zastosowania programu minimalistycznego, jest możliwość klasyfikowania gramatyk. W analizowanym przypadku historię języka angielskiego można scharakteryzować poprzez istnienie dwóch gramatyk, jedną charakteryzującą się mobilnym czasownikiem (okres staroangielski i średnioangielski) oraz drugą charakteryzującą się niemobilnym czasownikiem (okres nowoangielski). Takie założenie pozwala postawić hipotezę, że w pewnym okresie historii języka angielskiego, na pewnym obszarze Wielkiej Brytanii kolejne pokolenia były dwugramatyczne i w miarę upływu czasu następne pokolenia, preferując jedną gramatykę, wysyłały drugą w niebyt. Jest to możliwe wytłumaczenie zmiany składniowej, a tym samym kolejna korzyść, płynąca z zastosowania podejścia minimalistycznego.

\section{Program minimalistyczny beneficjentem badań diachronicznych}

Sam program minimalistyczny może być beneficjentem badań diachronicznych, gdyż analiza danych językowych, pochodzących $\mathrm{z}$ języka nieprzerwanie używanego na danym terytorium przez kolejne pokolenia użytkowników, przy założeniu ciągłości komunikacyjnej, może dostarczyć przesłanek do zmodyfikowania pewnych elementów tego paradygmatu. Przykładem niech będzie obecność czasownika posiłkowego do w pytaniach czy obecność elementów ekspletywnych there i it $\mathrm{w}$ pewnych typach zdań. Z powodu ograniczeń, nałożonych ramami niniejszej publikacji, ten ostatni problem nie będzie poruszany, gdyż jest to materiał na oddzielne opracowanie. Jeżeli założy się, że 
pytania są powiązane z odpowiadającymi im zdaniami twierdzącymi poprzez ten sam materiał leksykalny, to pojawienie się czasownika posiłkowego do w pytaniu jest kłopotliwe, gdyż nie ma go w zdaniu twierdzącym, a zatem nie ma go również w podstawowym zestawie leksykalnym (Lexical Array). Podstawowy zestaw leksykalny będzie przydatny do prześledzenia derywacji pytań w okresach staro- i średnioangielskim. Na przykład podstawowym zestawem leksykalnym dla staroangielskiego pytania:

(2) Gehyrst pu...?

Czy (ty) słyszysz?

będzie zbiór elementów leksykalnych $\mathrm{LA}=\{\mathrm{pu}$; gehyrst $\}$, które będą również leżały u podstaw derywacji twierdzącego zdania:

\section{(3) Pu gehyrst}

Ty słyszysz

Zdanie (2) jest wynikiem derywacji, w której jednostka leksykalna gehyrst jest przemieszczona i doczepiona do T, przez co stworzona jest domena sprawdzania dla $\mathrm{T}$. Ta operacja jest potrzebna po to, aby $\mathrm{T}$ mogło sprawdzić swoją cechę rzeczownikową $\mathrm{z}$ wyrażeniem rzeczownikowym, które pozostaje nadal w obrębie VP. Po utworzeniu domeny sprawdzającej, element $b u$ przemieszczony jest do określnika (specifier) $\mathrm{T}$ i tam następuje sprawdzenie i ewaluacja cechy nominalnej, obecnej na obydwu elementach. Te operacje odbywają się w komponencie jawnym, tj. między operacja - łącz (Merge) a punktem przekazania (Spell-Out). Obecność cech mocnych w $\mathrm{C}$ wymaga przemieszczenia formy gehyrst do C. Ta operacja jest również dokonywana w komponencie jawnym, czego odzwierciedleniem jest (2). Należy zauważyć, że ta derywacja jest w zgodzie z zasadą inkluzywności (Inclusiveness Principle), która ogranicza liczbę elementów obecnych w derywacji do tych, które są obecne w zestawie leksykalnym (Lexical Array) i numeracji. To znaczy, że nie można niczego dodawać ani ujmować w trakcie derywacji.

Jak nietrudno zauważyć, derywacja nowoangielskiego odpowiednika (2):

(4) Do you hear?

posiada dodatkowy element, który nie pojawia się w podstawowym zestawie leksykalnym. Gdybyśmy chcieli wywieść (4), którego podstawowy zestaw leksykalny jest LA $=\{$ you; hear $\}$, to pogwałcilibyśmy zasadę inkluzywności (Inclusiveness Principle). Jest to problem empiryczny i teoretyczny, który jak 
dotąd nie doczekał się dostatecznego wyjaśnienia. Rozwiązaniem byłoby wprowadzenie założenia modyfikującego początkowe etapy derywacji. Ta modyfikacja mogłaby polegać na założeniu, że każde tworzenie zestawu leksykalnego jest zapoczątkowane przez specyfikację illokucyjną danego zdania, co determinowałoby liczbę elementów leksykalnych i funkcyjnych w zestawie leksykalnym. I tak, dla (3) zestaw leksykalny zawierałby takie elementy, jak $\mathrm{LA}=\{\mathrm{IF}-$ statement $\{$ you, hear $\}\}$, a dla (4) ten zestaw można byłoby przedstawić jako LA $=\{I F-i n t e r r o g a t i o n\{d o$, you, hear $\}$, gdzie IF to siła illocucyjna (Illocutionary Force), a statement i interrogation są jej specyfikacjami, tj. odpowiednio, twierdzenie i pytanie. Taka specyfikacja pozwalałaby na determinowanie cech spójnika wprowadzającego zdanie i jego realizację na planie fonologicznym. Dla porównania, zestaw leksykalny dla (2) byłby $L A=\{I F-i n t e r r o g a t i o n$ $\{\mathrm{pu}$; gehyrst $\}$, a dla (3) byłby $\mathrm{LA}=\{\mathrm{IF}-\mathrm{statement}\{\mathrm{pu}$; gehyrst $\}\}$. Różnica między (2) a (4) leży w fakcie, że zestaw leksykalny zawiera dodatkowy element formalny $\mathrm{w}$ postaci czasownika posiłkowego do, który służy jako formalny środek doczepiony do spójnika wprowadzającego zdanie pytające i funkcjonujący jako rekompensata za utratę możliwości przemieszczenia formy hear w komponencie jawnym derywacji. Taką nieznaczną modyfikację początkowych faz derywacji można uznać za korzyść płynącą dla programu minimalistycznego z badań diachronicznych.

\section{Wnioski}

Program minimalistyczny nie może wyjaśnić, jaki mechanizm stał za zanikiem fleksji. Zakłada się, że w zestawie leksykalnym pojawiają się elementy już odmienione. A zatem zanik fleksji jest zjawiskiem pozaskładniowym i leży bardziej w domenie leksykonu. Ale za to można badać, jaki wpływ stopień defleksyjności danego języka ma na derywację syntagm. Która jej część będzie się realizowała między operacją - łącz (Merge) a punktem, względnie punktami, przekazania (Spell-Out), a która po tym punkcie, względnie punktach, jaką rolę odgrywają końcówki fleksyjne lub ich brak w interpretowalności danego tworu językowego. Stąd wynika, że program minimalistyczny będzie się koncentrował na jednym tylko aspekcie kompetencji językowej, tj. składni, która jest postrzegana jako medium pomiędzy dźwiękiem a znaczeniem/interpretacją. Ma to swoje zalety. Do zalet można zaliczyć (a) dobrze zdefiniowany obiekt opisu, (b) możliwość sklasyfikowania gramatyk poprzez pewne aspekty derywacji, (c) możliwość wytłumaczenia zmiany składniowej poprzez hipotezę wielogramatyczności użytkownika danego języka w danym okresie. Te trzy aspekty 
stanowią jednak kres możliwości eksplikacyjnych programu minimalistycznego w badaniach diachronicznych.

Jak zauważono na początku tego szkicu, język jest zjawiskiem wielopoziomowym, którego nie da się opisać w całości jednym paradygmatem. $\mathrm{Z}$ tego też wynikają ograniczenia programu minimalistycznego w badaniach diachronicznych. Jeżeli poprzez użycie instrumentarium minimalistycznego można opisać i sklasyfikować typy gramatyk, które są używane na danym terytorium w określonym czasie, i zakładając, że w badanym okresie użytkownicy są dwulub więcej gramatyczni, to typowanie, która gramatyka jest najbardziej preferowana i przez to wypierająca inne gramatyki, leży poza możliwościami eksplikacyjnymi programu minimalistycznego. Wyjaśnienia tego faktu należy szukać raczej w analizach i rozważaniach socjolingwistycznych, które będą brały pod uwagę elementy ekologii językowej.

Reasumując powyższe rozważania, program minimalistyczny służy jako perspektywa badawcza $w$ badaniach diachronicznych, pozwalająca dobrze rozpoznać opisywany obiekt. Obiektem tym jest składnia, opisywana jako wynik derywacji, funkcjonującej jako medium pomiędzy dźwiękiem a znaczeniem. Oznacza to, że zmiany fonologiczne i, po części, morfologiczne, jak również leksykalne, będą leżały poza możliwościami opisowymi tego paradygmatu. Instrumentarium programu minimalistycznego pozwala na postulowanie typów gramatyk i ich klasyfikację. To, z kolei, prowadzi do hipotezy wielogramatyczności użytkowników danego języka, gdzie najbardziej preferowana gramatyka wypiera inne typy gramatyk. Ta hipoteza dobrze tłumaczy zmiany składniowe. Wyżej wymienione aspekty stanowią korzyści płynące z zastosowania programu minimalistycznego w badaniach diachronicznych. Przyczyny, dla których jedna gramatyka wypiera inne, leżą również poza możliwościami eksplikacyjnymi tego paradygmatu i stanowią jedno z jego ograniczeń.

\section{Bibliografia}

Allen, C. L. 1995. Case Marking and Reanalysis: Grammatical Relations from Old to Early Modern English, Oxford: Clarendon Press.

Chomsky, N. 1995. The Minimalist Program, Cambridge, MA: MIT Press.

Chomsky, N. 1999. „Derivation by phase”, The MIT Occasional Papers in Linguistics 18.

Chomsky, N. 2000. „Minimalist inquiries: the framework”, [w:] R. Martin, D. Michaels,

J. Uriagereka (red.), 89-156.

Croft, W. 2003. Typology and Universals, Cambridge: Cambridge University Press.

Denison, D. 1993. English Historical Syntax: Verbal Constructions, London: Longman. 
Długosz-Kurbaczowa, K., Dubisz, S. 2006. Gramatyka historyczna języka polskiego, Warszawa: Wydawnictwa UW.

Hinzen, W. 2009. Mind Design and Minimal Syntax, Oxford: Oxford University Press.

Hogg, R. M. (red.). 1992-1999. The Cambridge History of the English Language 1-7, Cambridge: Cambridge University Press.

Klemensiewicz, Z. 1974. Historia języka polskiego, Warszawa: PWN.

Martin, R., Michaels, D. Uriagereka, J. 2000. Step by Step: Essays on Minimalist Syntax in Honor of Howard Lasnik, Cambridge, MA: MIT Press.

McMahon, A. M. S. 1994. Understanding Language Change, Cambridge: Cambridge University Press.

Perlin, J. 2004. Metodologia językoznawstwa diachronicznego, Warszawa: Dialog.

Polański, K. (red.), 1993. Encyklopedia językoznawstwa ogólnego, Wrocław: Ossolineum.

Roberts, I. G. 2007. Diachronic Syntax, Oxford: Oxford University Press.

Rospond, S. 1971. Gramatyka historyczna języka polskiego, Warszawa: PWN.

Stalmaszczyk, P. (red.), 2006. Metodologie językoznawstwa: podstawy teoretyczne, Łódź: Wydawnictwo UŁ.

Tajsner, P. 2006. „Minimalizm: przełom i kontynuacja”, [w:] P. Stalmaszczyk (red.), 91-107.

Thomason, D. S., Kaufmann, T. 1988. Language Contact, Creolization and Genetic Linguististics, Berkley: University of California Press.

Traugott, C. E. 1992. „Syntax”, [w:] R. M. Hogg (red.), 168-289.

Visser, F. T. 1963-1971. An Historical Syntax of the English Language 1-4, Leiden: E. J. Brill. 